\title{
Defective Interferon Gamma Production in Neonatal T Cells Is Independent of Interleukin-2 Receptor Binding
}

\author{
URSULA VON FREEDEN, NORBERT ZESSACK, FRANS VAN VALEN, AND STEFAN BURDACH \\ Department of Pediatric Hematology/Oncology, Heinrich-Heine-University Medical Center,
} 4000 Düsseldorf 1, Germany

\begin{abstract}
Newborns are more susceptible to fungal, viral, protozoan, and certain bacterial infections than adults. This susceptibility is due in part to a decreased interferon gamma (IF $\gamma$ ) production. The present investigation focuses on the role of the IL-2 receptor in the deficient IF $\gamma$ production in neonatal T cells. IL-2-induced IF $\gamma$ production in unstimulated neonatal cord blood and adult peripheral $T$ cells was comparable, but the IF $\gamma$ production in CD3-stimulated neonatal $T$ cells was only $20 \%$ of the adult production. Neonatal and adult $T$ cells showed no difference in the expression of the $55-\mathrm{kD} \alpha$ and 75-kD $\beta$ chains of the IL-2 receptor. Blocking of the 55$\mathrm{kD} \alpha$ chain of the IL2 receptor with TAC MAb resulted in a marginal reduction in IF $\gamma$ release from unstimulated or CD3-stimulated neonatal $\mathrm{T}$ cells cultured in the presence of IL-2. In contrast, blocking of the 55-kD $\alpha$ chain of the IL-2 receptor in adult $T$ cells caused a $92 \%$ and $73 \%$ inhibition in IF $\gamma$ production in unstimulated and stimulated $T$ cells, respectively. Blocking of the $75-\mathrm{kD} \beta$ chain of the IL-2 receptor with TU27 MAb had a marginal effect in both unstimulated and CD3-stimulated neonatal and adult lymphocytes. Binding studies with unstimulated cord blood T cells using $\left[{ }^{125} \mathrm{I}\right]-\mathrm{IL}-2$ showed a binding affinity that corresponded with the intermediate affinity IL-2 receptor. In CD3-stimulated cord blood $\mathrm{T}$ cells, a high-affinity receptor was found. The addition of TAC MAb blocked binding to the high-affinity receptor and resulted in IL-2 binding with intermediate affinity. Northern analysis showed an IL-2-induced accumulation of IF $\gamma$ mRNA in unstimulated and stimulated neonatal $T$ cells. In contrast to adult $T$ lymphocytes, TAC MAb did not cause a decrease in IL-2induced IF $\gamma$ mRNA expression in CD3-stimulated neonatal lymphocytes. These data suggest that cord blood $T$ lymphocytes express normal IL-2 receptors and are able to form a functional intact high-affinity $\mathrm{IL}-2$ receptor complex. However, neonatal T cells do not up-regulate IF $\gamma$ production in response to IL-2. (Pediatr Res 30: 270 - 275, 1991)
\end{abstract}

\section{Abbreviations}

IF $\gamma$, interferon gamma

NAB, nonadherent buoyant mononuclear cells

p55, $55 \mathrm{kD} \alpha$ chain of the IL-2 receptor

p75, $75 \mathrm{kD} \beta$ chain of the IL-2 receptor

PBS/ $\mathrm{NaN}_{3} / \mathrm{FCS}, \mathrm{PBS}$ containing $0.3 \%$ sodium azide and $2 \%$ FCS

Received August 6, 1990; accepted March 8, 1991

Correspondence and reprint requests: Dr. Stefan Burdach, Kinderklinik, Abt. für Hämatologie und Onkologie, Heinrich-Heine-Universität, 4000 Düsseldorf 1 , Germany.

Supported by grants from Deutsche Forschungsgemeinschaft (BU 578/2-2) and Elterninitiative Kinderkrebsklinik, Düsseldorf e.V.
PE, phycoerythrin

PGE, prostaglandin E

SSPE, sodium chloride, sodium phosphate, EDTA

TNF, tumor necrosis factor

The incidence of life-threatening infections is higher in human newborns than in adults. Infections remain a leading cause of neonatal death. This unique susceptibility of the newborn to fungal, viral, protozoan, and certain bacterial infections (1-3) has fostered many investigations of various immunologic parameters. We focused our investigation on the decreased IF $\gamma$ production (4-6) in neonatal T cells.

The lymphokine IF $\gamma$, which has antiviral activity and antitumor effects, is thought to play a central role in the regulation of immune response (7-9). IF $\gamma$ can inhibit virus replication and growth of intracellular parasites. IF $\gamma$ appears to be an important macrophage activating factor. It enhances the phagocytic activity of macrophages, increases the oxidative metabolism in macrophages (10), and mediates antimicrobial functions against intracellular pathogens such as Candida, Toxoplasma gondii, Trypanosome cruzi, Leishmania, and mycobacteria $(8,11)$. IF $\gamma$ is produced by $\mathrm{T}$ lymphocytes. The cellular origin of IF $\gamma$ among T cell subpopulations depends on the stimulus applied. T helper cells $\left(\mathrm{T}^{+}\right)$produce $\mathrm{IF} \gamma$ in response to $\mathrm{CD} 3$ antibody in the presence of $\mathrm{CD} 11 \mathrm{~b}$ positive cells including macrophages (7). Both CD4 and CD8 activated T cells produce IF $\gamma$ in response to IL-2 (12). Thus, the regulation of IF $\gamma$ is based on an interaction between antigen presenting cells and $T$ cells and is mediated by IL-2 (12-14).

IL-2 is a lymphokine also produced by $\mathrm{T}$ lymphocytes in response to IL-1, mitogen, or antigen stimulation (15). IL-2 serves as a growth factor for several subsets of $\mathrm{T}$ cells, B cells, and activated natural killer cells. IL-2 stimulates the production of IF $\gamma$, TNF- $\alpha$, TNF- $\beta$, and granulocyte-macrophage colony stimulating factor in peripheral mononuclear blood cells (16). IL-2 exerts its functional effects through binding to specific membrane receptors $(17,18)$. So far, two surface IL-2-binding proteins on human $T$ cells have been identified and their cDNAs have been cloned: $\mathrm{p} 55$ and $\mathrm{p} 75$. The $\mathrm{p} 55$ subunit binds IL-2 with low affinity $\left(\mathrm{k}_{\mathrm{d}} \approx 10^{-8} \mathrm{M}\right)$ and the p75 subunit binds with intermediate affinity $\left(\mathrm{k}_{\mathrm{d}} \approx 10^{-9} \mathrm{M}\right)$, whereas a dimeric receptor composed of both p55 and p75 binds IL- 2 with high affinity ( $k_{d}$ $\left.\approx 10^{-11} \mathrm{M}\right)(19,20)$. The $\mathrm{p} 75$ receptor is present on a subset of unstimulated $\mathrm{T}$ cells, whereas the high-affinity receptor is expressed after activation of $T$ lymphocytes by antigen presentation to the $\mathrm{T}$ cell antigen receptor complex. In addition, IL-2 has been shown to induce its own high-affinity receptor in $\mathrm{T}$ cells $(21,22)$. p 75 contains a functional domain to mediate IL-2 signal transduction across the membrane, and p55 is thought to coop- 
erate with the p75 chain to form high-affinity binding sites. It is not clear weather p55 itself may be capable of transducing a signal. It has been described that p55 is internalized together with p75 after IL-2 binding to the high-affinity receptor complex (23, 24). Endocytosis of p55 depends upon the presence of IL-2 interacting with the p75 subunit. Coupling of the IL-2 highaffinity receptor to signal transduction pathway, distinct from the p75 pathway, is one possibility of signal transduction. The second messenger of IL-2 signaling is not yet defined. It has been shown that neither protein kinase C, cAMP, nor cGMP serve as a second messenger (25-28). Recent results indicate that tyrosine phosphorylation is operational in IL-2 receptor signal transduction (29).

In this study we focused our interest on the molecular mechanism of neonatal IF $\gamma$ deficiency. Specifically we asked: 1 ) Is the p55 receptor chain membrane expression on neonatal T cells different from p55 expression on adult $T$ cells? 2) Is the p75 receptor chain membrane expression on neonatal $T$ cells different from p75 expression on adult T cells? 3) Is the IF $\gamma$ protein production in neonatal $\mathrm{T}$ cells dependent on $\mathrm{p} 55$ or $\mathrm{p} 75$ expression? 4) Is the IF $\gamma$ mRNA accumulation in stimulated neonatal T cells dependent on p55? 5) Are the binding conditions of the intermediate- and high-affinity IL-2 receptors in neonatal T cells different from adult cells?

\section{MATERIALS AND METHODS}

Blood Specimens. Heparinized cord blood samples were collected from the placental portion of the umbilical vein of fullterm infants immediately after birth. Venous peripheral blood from healthy adult volunteers served as the control. Studies were approved by the Ethics Committee of the Medical Center, Heinrich-Heine-Universität, Düsseldorf.

Cell Separation. Peripheral blood mononuclear cells were separated by Ficoll-Paque density gradient. The contamination of the mononuclear layer with red blood cells in cord blood samples necessitated erythrocyte lysis with ammonium chloride for $5 \mathrm{~min}$ at $4^{\circ} \mathrm{C}$. NAB were obtained after two 45 -min-incubation periods in polystyrol dishes with RPMI 1640 medium containing $10 \%$ FCS at $37^{\circ} \mathrm{C}$ in $5 \% \mathrm{CO}_{2}$. Contamination with monocytes (CD14/ Leu M3 positive cells) and NK (Leu 7 positive cells) was assessed by flow cytometry analysis and calculated to be $7.5 \pm 1.3 \%$ for monocytes and macrophages and $1.5 \pm 0.4 \%$ for NK.

Cell Culture. NAB cells $\left(1 \times 10^{6}\right.$ cells $\left./ \mathrm{mL}\right)$ were cultured in RPMI 1640 supplemented with $10 \%$ pooled human AB-serum, L-glutamine, sodium-pyruvate and penicillin-streptomycin and different concentrations of IL-2. Before culture, NAB cells were incubated for $15 \mathrm{~min}$ at $4^{\circ} \mathrm{C}$ with anti-CD3 MAb (OKT3, Ortho Pharmaceuticals, Heidelberg, Germany) in a concentration of $0.1 \mu \mathrm{g} / \mathrm{mL}$ to activate T cells. T cell pellets were used to facilitate interaction between T cell LFA 3 and CD2. In some experiments, before activation and culture with IL-2, cells were treated with either p55-blocking TAC MAb (provided by T. Waldmann, NIH, Bethesda MD) (30) or p75-blocking TU27 MAb (provided by K. Sugamura, Tohoku University and S. Taki, Aujinomoto Co., Kawasaki, Japan) $(31,32)$. TU27 MAb was used at concentrations varying from 41 to $410 \mathrm{nmol}$ and TAC MAb at concentrations between 6.8 and $68.5 \mathrm{nmol}$. The IL-2 quantity we used was 100 Cetus Units/mL, which is equivalent with $2 \mathrm{nmol}$ IL-2. Thus, the highest molar excess of TAC MAb and TU27 MAb to IL-2 was 34-fold and 205-fold, respectively.

Protein Immunoassay. IF $\gamma$ protein production was assessed in supernatants of cell cultures $\left(1 \times 10^{6}\right.$ cells $\left./ \mathrm{mL}\right)$ after $4-\mathrm{d}$ culture periods by solid-phase RIA (Centocor Inc., Malverna, PA). The sensitivity of the assay is $0.1 \mathrm{U} / \mathrm{mL}$ of a NIH reference standard.

Flow Cytometry. Direct immunofluorescence. NAB cells $(1 \times$ $10^{6}$ ) were washed twice with $\mathrm{PBS} / \mathrm{NaN}_{3} / \mathrm{FCS}$. The cell pellets were incubated with MAb conjugated with FITC or PE.

Indirect immunofluorescence. NAB cells $\left(1 \times 10^{6}\right)$ were washed twice in $\mathrm{PBS} / \mathrm{NaN}_{3} / \mathrm{FCS}$ and incubated for $30 \mathrm{~min}$ at room temperature with goat serum to block Fc-receptors. Cell pellets were then incubated with the unconjugated $\mathrm{MAb}$ for $5 \mathrm{~min}$ at $4^{\circ} \mathrm{C}$. After two washes in PBS/ $\mathrm{NaN}_{3} / \mathrm{FCS}$, cells were incubated for an additional $5 \mathrm{~min}$ at $4^{\circ} \mathrm{C}$ with PE-labeled goat-antimouse IgG1.

Double labeling. Cells were indirectly labeled with unconjugated mouse-anti-human p75 antibody and stained with PEconjugated goat-anti-mouse IgG1 antibody. Next, free binding sites on the goat IgG1 antibody were blocked with mouse serum. Cells were then stained with different FITC-labeled antibodies.

Labeled cells were washed twice and suspended in $500 \mu \mathrm{L}$ $0.5 \%$ PBS-paraformaldehyde fixative solution. Samples were analyzed on a FACScan (Becton Dickinson, Parsippany, NJ) and data were processed by using the Consort 30 or the FACS Star Plus program.

IL-2 Receptor Binding Assays Using [ $\left.{ }^{125} I\right]-I L-2$. Cells were washed twice in PBS/FCS to remove endogenous IL-2 and immediately used for binding experiments. To determine the level of binding, $1-4 \times 10^{6}$ cells were incubated with serial dilutions of $\left[{ }^{125} \mathrm{I}\right]-\mathrm{IL}-2$ [(3-[ $\left.{ }^{125} \mathrm{I}\right]$ isodotyrosyl)-IL-2, Amersham Buchler, Braunschweig, Germany] for $35 \mathrm{~min}$ at $37^{\circ} \mathrm{C}$ in $5 \%$ $\mathrm{CO}_{2}$. Cells were suspended in a total volume of $60-70 \mu \mathrm{L}$ of RPMI 1640 supplemented with $10 \%$ pooled human AB-serum, L-glutamine, sodium-pyruvate, and penicillin-streptomycin. To determine unspecific binding, cells were incubated with a 500fold excess of unlabeled IL-2. In some experiments, the cells were preincubated with $100 \mathrm{nmol} \mathrm{TAC} \mathrm{MAb}$ for $15 \mathrm{~min}$ at $4^{\circ} \mathrm{C}$ to block the p 55 chain of the high-affinity receptor. The incubation was performed in polypropylene tubes, pretreated with BSA for 4-6 hours at $37^{\circ} \mathrm{C}$ to avoid nonspecific binding to the tubes. After incubation, cells were kept on ice and washed twice with cold PBS/FCS. Radioactivity of the cell pellets and total added activity were determined by a gamma-counter. The $\mathrm{k}_{\mathrm{d}}$ was determined by Scatchard analysis of equilibrium binding data after substraction of nonspecific binding.

RNA Extraction and Northern Analysis. Cells were incubated for $16 \mathrm{~h}$ at $37^{\circ} \mathrm{C}$ in $5 \% \mathrm{CO}_{2}$. Total cellular RNA was extracted with phenol in the presence of vanadyl ribonucleoside complexes. Integrity and amount of ribosomal RNA were confirmed by electrophoresis of $1 \mu \mathrm{g}$ RNA in $1 \%$ agarose gels and staining with ethidium bromide. Ten to $15 \mu \mathrm{g}$ of total RNA was separated by $1.2 \%$ agarose-formaldehyde gel electrophoresis and transferred to nylon membranes (Schleicher and Schüll, Dassel, Germany) by capillary blotting. Transferred RNA labeled with ethidium bromide was fixed to the membrane by short wave UV radiation. Documentation by photography under UV-light was made to ensure that equal amounts were loaded onto each lane.

Prehybridization was carried out in a solution containing $6 \times$ SSPE, $0.2 \%$ SDS, $1 \times$ Denhardts, and $60 \mu \mathrm{g} / \mathrm{mL}$ denaturated salmon sperm DNA up to $4 \mathrm{~h}$ at $50^{\circ} \mathrm{C}$. Filters were hybridized overnight in the same solution containing a ${ }^{32} \mathrm{P}$-labeled PstI IF $\gamma$ cDNA fragment (30a). The ${ }^{32} \mathrm{P}$-labeling was performed using the Random Primed DNA Labeling Kit (Böehringer, Mannheim, Germany). After hybridization, filters were washed in $6 \times$ SSPE, $2 \%$ SDS for $10 \mathrm{~min}$ at room temperature, followed by washing with $2 \times \mathrm{SSPE}, 1 \% \mathrm{SDS}$ for $20 \mathrm{~min}$ at $60^{\circ} \mathrm{C}$. For autoradiography filters were exposed to x-ray film (3M, St. Paul, MN) with intensifier screen at $-70^{\circ} \mathrm{C}$.

Statistics. Results are expressed as mean \pm SEM. Student's $t$ test for paired observations was used for parametrics distributions and Wilcoxon signed-rank test was used for nonparametrics distributions.

\section{RESULTS}

IF $\gamma$ protein production. Unstimulated and CD3-stimulated cord blood and adult $\mathrm{T}$ cells were cultured at a concentration of $1 \times 10^{6}$ cells $/ \mathrm{mL}$ in the presence or absence of $100 \mathrm{U} \mathrm{IL}-2 / \mathrm{mL}$ to assess the effect of IL-2-induced IF $\gamma$ production. Supernatants were harvested at $\mathrm{d} 4$ of culture, and IF $\gamma$ protein secretion was 
assessed by immunoassay (Fig. 1). In unstimulated $\mathrm{T}$ cells the IL-2-induced IF $\gamma$ release was similar in cord blood and adult blood, in cord blood from $8.1 \pm 4.0 \mathrm{U} / \mathrm{mL}$ to $205.3 \pm 66.9 \mathrm{U} /$ $\mathrm{mL}(n=20 ; p=0.007)$, and in adult blood from $12.3 \pm 3.2 \mathrm{U} /$ $\mathrm{mL}$ to $217.3 \pm 46.4 \mathrm{U} / \mathrm{mL}(n=21 ; p<0.001)$. In CD3stimulated cells, the adult T cells cultured without IL-2 already released $256.6 \pm 70.1 \mathrm{U} / \mathrm{mL} \mathrm{IF} \gamma$, and with IL-2 there was an upregulation of IF $\gamma$ production to $1189.1 \pm 152.9 \mathrm{U} / \mathrm{mL}(n=$ $19 ; p<0.001)$. The stimulated cord blood cells secreted $12.8 \pm$ $4.8 \mathrm{U} / \mathrm{mL}$ without IL-2 and $238.3 \pm 55.3 \mathrm{U} / \mathrm{mL}(n=22 ; p<$ 0.001 ) in the presence of IL-2. There was no significant difference between the IF $\gamma$ production of unstimulated and CD3-stimulated cord blood cells.

The dose-response curve for IL-2-induced IF $\gamma$ production showed a half-maximal stimulation at $26 \mathrm{U} / \mathrm{mL}$ IL-2 with unstimulated neonatal $\mathrm{T}$ cells, the same as that found in unstimulated adult $\mathrm{T}$ cells. These concentrations are comparable with those necessary to bind the isolated p75 subunit of the IL-2 receptor. With CD3-stimulated neonatal T cells the half-maximal stimulation was about $17 \mathrm{U} / \mathrm{mL}$ IL-2. In contrast, half-maximal stimulation in adult lymphocytes was about $3 \mathrm{U} / \mathrm{mL}$ IL-2. Because 1-4 U/mL IL-2 already saturates the high-affinity receptor, IF $\gamma$ production in neonatal T cells seems not to be regulated by the high-affinity receptor for IL-2.

Cytofluorographic analysis. Cell surface antigen expression on lymphocyte gated cells was assessed by flow cytometry. Cord blood and adult $\mathrm{T}$ cells expression of $\mathrm{p} 55$ (stained with the direct conjugated antibody CD25, Becton Dickinson) was similar: unstimulated cord blood T cells expressed $6.2 \pm 0.7 \%$ p55 $(n=$ 14), unstimulated adult T cells $7.7 \pm 2.5 \%(n=7 ; p=0.49)$; after incubation for $4 \mathrm{~d}$ with IL-2, $12.1 \pm 2.2 \%(n=8)$ of cord blood cells and $16.1 \pm 3.7 \%(n=6 ; p=0.40)$ of adult cells were p55 positive. In CD3-stimulated T cells cultured without IL-2 $58.7 \pm 8.9 \%(n=6)$ of cord blood cells and $45.8 \pm 4.8 \%(n=$ $7 ; p=0.30$ ) of adult blood cells were p55-positive. In CD3stimulated cells cultured with IL-2, 78.1 $\pm 4.8 \%(n=6)$ of cord blood cells and 75.1 $\pm 9.4 \%(n=6 ; p=0.77)$ of adult blood cells were positive for p55 (Fig. 2). Thus, CD3-induced p55 expression as well as IL-2-induced upregulation of p55 in stimulated cells is similar in neonatal and adult T cells.

p75 expression was assessed by indirect fluorescence analysis with TU27 MAb: $19.2 \pm 2.1 \%(n=8)$ of unstimulated cord blood T cells expressed p75, and $18.2 \pm 2.1 \%(n=5)$ of adult T cells expressed $\mathrm{p} 75$. Double staining showed that $\mathrm{p} 75$ was present in $42.8 \pm 5.5 \%(n=5)$ of $\mathrm{T}^{+}$neonatal $\mathrm{T}$ cells and only in 4.0 $\pm 1.7 \%(n=5)$ of $\mathrm{T}^{+}$neonatal T lymphocytes. These data are comparable with results obtained from adult $\mathrm{T}$ cells $(19,31)$.

IL-2 binding studies. We next examined IL-2-binding activity to unstimulated and stimulated neonatal $\mathrm{T}$ cells using [ $\left.{ }^{125} \mathrm{I}\right]$-IL2. Scatchard plot analysis showed a $\mathrm{k}_{\mathrm{d}}$ of $425.7 \pm 116.4 \mathrm{pmol}$

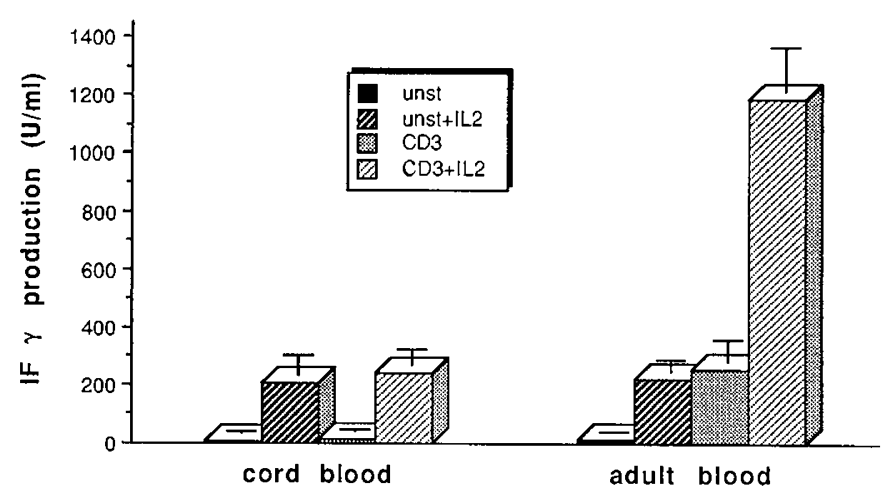

Fig. 1. IF $\gamma$ release from neonatal and adult $T$ cells. Unstimulated and CD3-stimulated neonatal and adult blood $T$ cells $\left(1 \times 10^{6}\right.$ cells $\left./ \mathrm{mL}\right)$ were cultured in the presence or absence of $100 \mathrm{U} / \mathrm{mL}$ IL-2. The IF $\gamma$ release was assessed in the cell culture supernatants. Results are expressed as mean \pm SEM from 19 to 22 different experiments. $(n=5)$ in unstimulated neonatal T cells, which corresponds with the intermediate affinity receptor. In stimulated $\mathrm{T}$ cells, radiolabeled IL-2 bound to the high-affinity receptor with a $\mathrm{k}_{\mathrm{d}}$ of 58.3 $\pm 13.6 \mathrm{pmol}(n=5)$. An example of one study is given in Figure 3. In unstimulated adult $\mathrm{T}$ cells a $\mathrm{k}_{\mathrm{d}}$ of $366.7 \pm 25.2 \mathrm{pmol}(n=$ 3 ) was found, and in stimulated $T$ cells the $k_{d}$ value was calculated to be $64.0 \pm 8.7 \mathrm{pmol}(n=3)$. This corresponds to the described affinities for the intermediate- and the high-affinity receptors, respectively $(17,18,24)$.

Blockade of the $p 55$ and $p 75$ IL-2 receptors. To assess the relative roles of the $\mathrm{p} 55$ and $\mathrm{p} 75$ receptor subunits in mediating IL-2-induced IF $\gamma$ production, we used receptor-specific blocking MAb. Unstimulated and CD3-stimulated T cells were incubated with the p75-blocking TU27 MAb or the p55-blocking TAC MAb prior to culture with IL-2. In cord blood T cells, inhibition with the p75-blocking TU27 MAb $(12 \mu \mathrm{g} / \mathrm{mL})$ showed a reduction in IF $\gamma$ production: in unstimulated cells from $36.7 \pm 8.2$ $\mathrm{U} / \mathrm{mL}$ to $13.4 \pm 2.4 \mathrm{U} / \mathrm{mL}(65 \%)(n=6 ; p=0.02)$, as well as in stimulated cells from $116.7 \pm 42.5 \mathrm{U} / \mathrm{mL}$ to $61.3 \pm 28.6 \mathrm{U} /$ $\mathrm{mL}(48 \%)(n=6 ; p=0.03)$. In unstimulated adult $\mathrm{T}$ lymphocytes, IF $\gamma$ production was decreased from $218.3 \pm 85.5 \mathrm{U} / \mathrm{mL}$ to $163.6 \pm 96.7 \mathrm{U} / \mathrm{mL}(25 \%)(n=3 ; p=0.05)$, and in stimulated $\mathrm{T}$ cells IF $\gamma$ levels were reduced from $667.7 \pm 83.3 \mathrm{U} / \mathrm{mL}$ to $608.3 \pm 58.3 \mathrm{U} / \mathrm{mL}(9 \%)(n=3 ; p=0.14)$ (Fig. 4). The absolute amount of IF $\gamma$ blocked with TU27 MAb in adult T cells (54.7 $\mathrm{U} / \mathrm{mL}$ in unstimulated and $59.4 \mathrm{U} / \mathrm{mL}$ in stimulated cells) is comparable to the absolute amount found in neonatal $\mathrm{T}$ cells (23.4 U/mL in unstimulated and $55.5 \mathrm{U} / \mathrm{mL}$ in stimulated cells).

In neonatal $\mathrm{T}$ cells, blockade of the p55 receptor unit with TAC MAb resulted in a reduction of IF $\gamma$ release of only $16 \%$ in unstimulated (from $202.9 \pm 91.3 \mathrm{U} / \mathrm{mL}$ to $170.2 \pm 84.3 \mathrm{U} / \mathrm{mL}$ ) ( $n=12 ; p=0.08)$ and $21 \%$ in stimulated cells $(262.5 \pm 84.7 \mathrm{U} /$ $\mathrm{mL}$ to $208.5 \pm 74.6 \mathrm{U} / \mathrm{mL})(n=12 ; p=0.08)$, whereas in adult $\mathrm{T}$ cells the reduction was $92 \%$ in unstimulated $(138.4 \pm 73.6 \mathrm{U} /$ $\mathrm{mL}$ to $10.6 \pm 2.5 \mathrm{U} / \mathrm{mL})(n=7 ; p=0.03)$ and $73 \%$ in stimulated cells $(843.2 \pm 219.6 \mathrm{U} / \mathrm{mL}$ to $231.6 \pm 71.4 \mathrm{U} / \mathrm{mL})(n=13 ; p=$ 0.02) (Fig. 5).

We next assessed the effect of TAC MAb inhibition on the binding affinity of IL-2 to its high-affinity receptor. CD3-stimulated neonatal T cells, cultured for $4 \mathrm{~d}$ in the presence of IL-2, were blocked with $100 \mathrm{nmol}$ TAC MAb before incubation with radiolabeled IL-2. We found a significant $(p=0.002)$ change in IL-2-binding properties from a binding with the high-affinity receptor $(58.3 \pm 13.7 \mathrm{pmol} ; n=5)$ to binding with the intermediate-affinity receptor $(615.0 \pm 117.2 \mathrm{pmol} ; n=4)$. An example of one study is given in Figure 6.

$I F \gamma m R N A$ expression. We next addressed the question of at which level of gene expression the defect in IF $\gamma$ protein release is located. In so doing we assessed whether IF $\gamma$ release is preceded by accumulation of IF $\gamma$ mRNA. Total RNA was isolated from unstimulated and CD3-stimulated T cells after $16 \mathrm{~h}$ of culture in the presence or absence of IL-2.

Northern analysis revealed that IL- 2 augments IF $\gamma$ mRNA in both unstimulated and stimulated neonatal $T$ cells. Next we investigated whether blockade of p55 membrane protein may block neonatal IF $\gamma$ mRNA accumulation as we have previously shown in adult T cells (32). Preincubation with TAC MAb to block p55 did not abrogate IL-2-induced IF $\gamma$ mRNA accumulation (Fig. 7).

\section{DISCUSSION}

Our data indicate that neonatal $T$ cells are capable of upregulating the affinity of their IL-2 receptor by forming a functional, intact high-affinity IL-2 receptor complex, but that, nevertheless, the neonatal $\mathrm{T}$ lymphocytes are not able to upregulate the IF $\gamma$ production in response to IL-2 binding to its high-affinity receptor. Neonatal lymphocytes may thus exhibit a specific defect in the production of IF $\gamma(33,34)$ but not in production of IL-2 $(5,34)$ or in expression of its IL-2 receptor. 


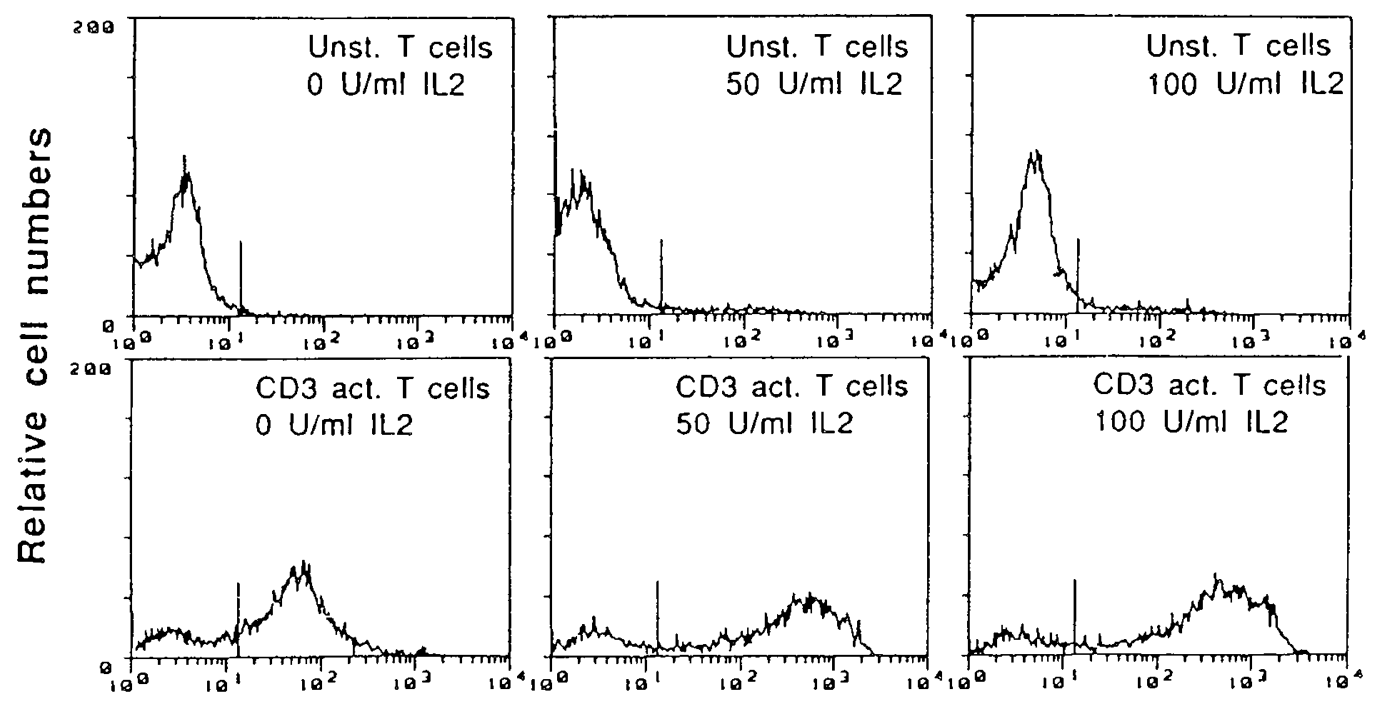

Fluorescence intensity of TAC expression

Fig. 2. p55 expression in neonatal $T$ cells. p55 expression in unstimulated and stimulated neonatal $T$ cells cultured with the indicated concentrations of IL-2 stained with the PE-conjugated CD25 MAb. The shift of the immunofluorescence profile to the higher fluorescence intensity (x-axis) shows an increase in the number of p55-binding sites. The graph shows a result of a representative experiment.

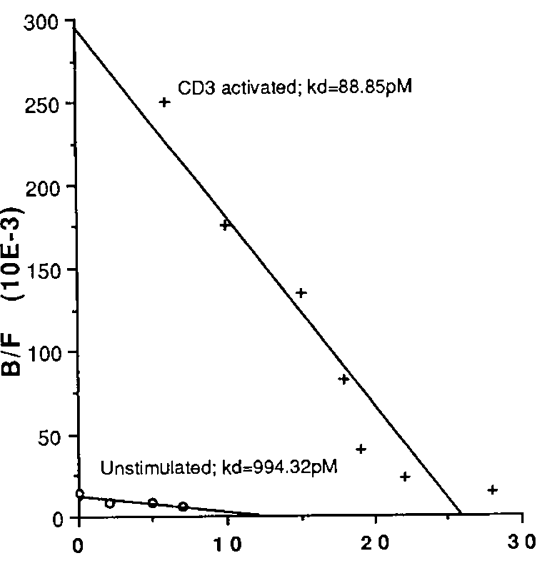

125 I IL2 bound spec. (pM)

Fig. 3. Binding of IL-2 to neonatal T cells. Scatchard transformation of data (B/F to bound spec.) of [ $\left.{ }^{125} \mathrm{I}\right]-\mathrm{IL}-2$ binding to unstimulated and CD3-stimulated neonatal $T$ cells cultured in the presence of $100 \mathrm{U} / \mathrm{mL}$ IL-2. The graph shows a result of a representative experiment.

The defect of IF $\gamma$ production in neonatal T cells can be located on different levels of induction of IF $\gamma$ gene expression. The number of IL-2 receptors expressed on neonatal T cells is comparable to that in adults, but the IL-2 receptor may exhibit a functional defect, e.g., an inability to mediate the transduction of the ligand-induced signal. TAC MAb blocks the IF $\gamma$ protein release in adult $\mathrm{T}$ cells but fails to block IF $\gamma$ in neonatal T cells. One possible interpretation of the data is that the p55 subunit of the high-affinity receptor may mediate the biologic signal. Previous reports indicate that transfection of p55 cDNA into nonlymphoid cells may confer responsiveness to IL-2 (35). Another possibility is that the p55 subunit activates the p75 subunit to mediate the biologic signal. Various studies have shown that the function of signal transduction is associated with $\mathrm{p} 75$, and the role of p 55 is mainly thought to increase the affinity of $\mathrm{p} 75$ for IL-2 $(27,36)$. Our results imply that in adult T cells, p55 participates in the biologic signal transduction, either by being the transducer itself or by functioning as an activator of $\mathrm{p} 75$. Presently, it is unclear by which receptor the residual neonatal IF $\gamma$ production is regulated. Unstimulated and stimulated neonatal $\mathrm{T}$ cells produce comparable amounts of IF $\gamma$ and are not

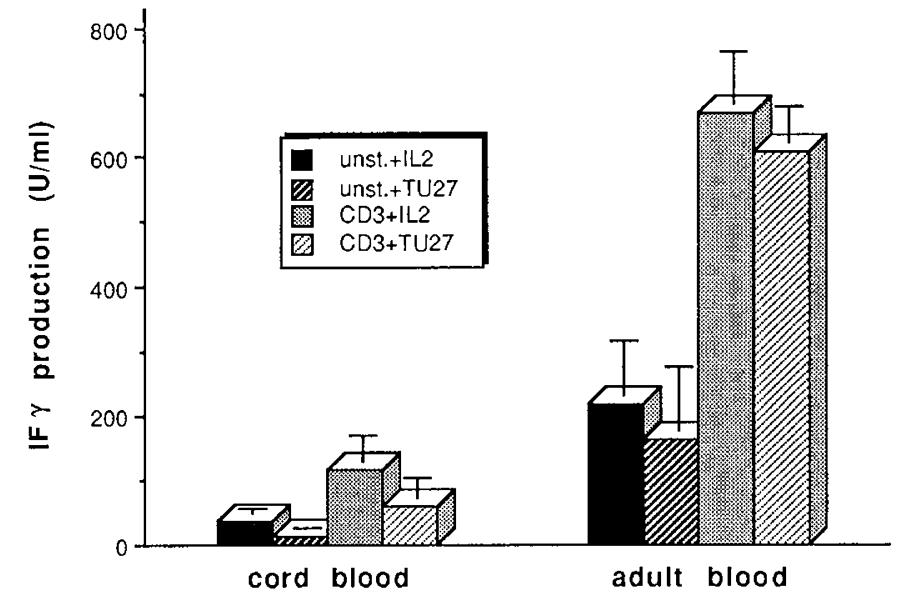

Fig. 4. Effect of p75 receptor blockade with TU27 MAb. Unstimulated and CD3-stimulated neonatal and adult T cells $\left(1 \times 10^{6}\right.$ cells $\left./ \mathrm{mL}\right)$ were cultured in the presence of $100 \mathrm{U} / \mathrm{mL}$ IL-2. Before culture the cells were blocked with $12 \mu \mathrm{g} / \mathrm{mL}$ TU27 MAb. Results are expressed as mean \pm SEM from six separate experiments with cord blood and three separate experiments with adult blood.

inhibited by TAC MAb or TU27 MAb. Thus IF $\gamma$ seems not to be regulated by the p 55 chain or the p75 chain of the IL-2 receptor. In adult $\mathrm{T}$ cells the IF $\gamma$ production is inhibited in stimulated and in unstimulated T cells by TAC MAb.

The defect of IF $\gamma$ release could also be a defect in signal transduction from the membrane to the gene. Increased cellular sensitivity to PGE of neonatal T cells (4) has been related to deficient IF $\gamma$ production. PGE down-regulates the CD2 expression, and $\mathrm{CD} 2$ plays an important role in the IF $\gamma$ regulation (37). Thus decreased neonatal IF $\gamma$ release may be due in part to interference of PGE with CD2-mediated activation. Of note, in our studies $\mathrm{T}$ cells were incubated in cell pellets to facilitate physical contact in cellular interaction of T cell LFA3 and its $\mathrm{CD} 2$ receptor. The activation of neonatal $\mathrm{T}$ cells via $\mathrm{CD} 2$ is defective (37). However, p55 expression is related to CD2 activation $(38,39)$. Of interest, neonatal $T$ cells express $\mathrm{p} 55$ in amounts at least comparable to that of adult $\mathrm{T}$ cells. Thus neonatal $\mathrm{T}$ lymphocytes may possess a mechanism to compen- 


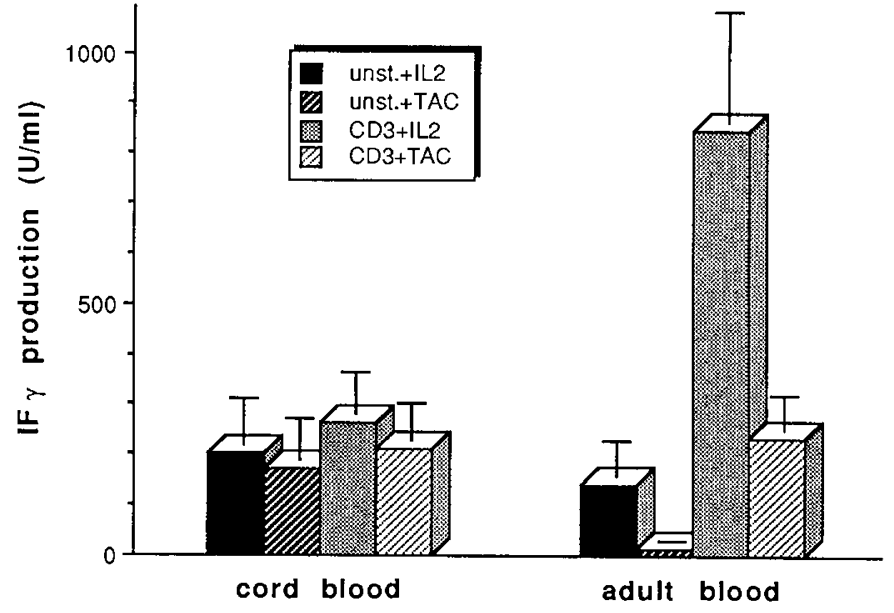

Fig. 5. Effect of p55 receptor blockade with TAC MAb. Unstimulated and CD3-stimulated neonatal and adult T cells $\left(1 \times 10^{6}\right.$ cells $\left./ \mathrm{mL}\right)$ were cultured in the presence of $100 \mathrm{U} / \mathrm{mL}$ IL-2. Prior to culture the cells were blocked with $1 \mu \mathrm{g} / \mathrm{mL}$ TAC MAb. Results are expressed as mean \pm SEM from 12 experiments with cord blood and 7 experiments with adult blood

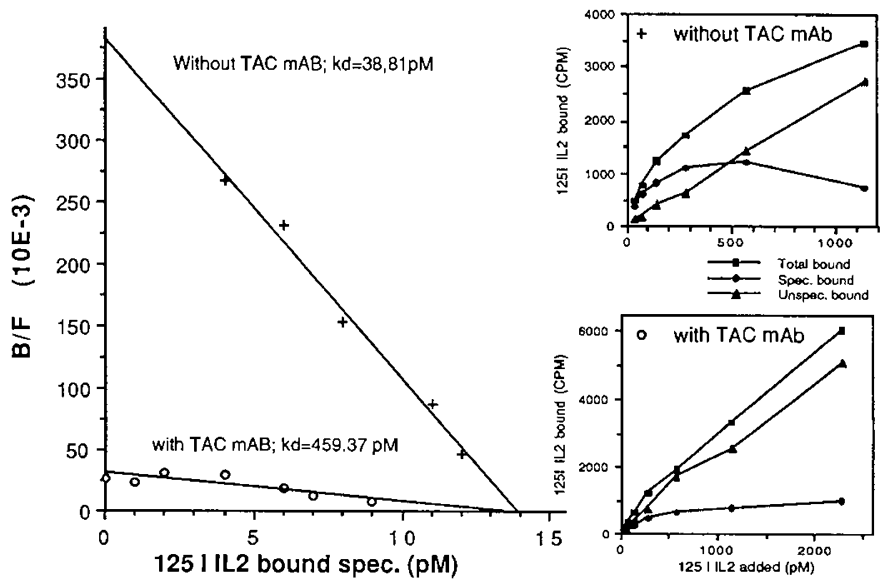

Fig. 6. TAC MAb inhibition of IL-2 binding. Scatchard transformation of data of binding of [ $\left.{ }^{125} \mathrm{I}\right]$-labeled IL-2 to CD3-stimulated neonatal $T$ cells after culture with IL-2 in the presence or absence of TAC MAb. The graph shows a result of a representative experiment.

sate defective $\mathrm{CD} 2$ activation with respect to $\mathrm{p} 55$ expression, but not IF $\gamma$ production.

A defect in the IF $\gamma$ DNA transcription could also result in the decreased IF $\gamma$ protein release. The accumulation of IF $\gamma$ mRNA in stimulated neonatal $\mathrm{T}$ cells is markedly decreased compared with the accumulation of IF $\gamma$ mRNA in adults (40). In contrast, amounts of TNF or lymphotoxin mRNA in neonatal T cells are comparable to the mRNA amounts in adult $T$ cells. Alternatively, decreased IF $\gamma$ mRNA levels in neonatal $T$ cells might be due to RNA processing and stabilization. These data indicate that the defect of IF $\gamma$ may be on a pretranslational level, whereas the defective TNF or lymphotoxin production may be due to a defect in RNA translation.

Taken together, these observations may help to understand the regulatory defect of IF $\gamma$ protein release in neonatal T cells. The increased incidence and severity of certain viral and protozoan infections such as cytomegalovirus, herpesvirus, rubella, or Toxoplasma gondii in newborns may be due at least in part to deficient IF $\gamma$ production.

Acknowledgments. The authors thank Dr. T. Waldmann for providing TAC MAb and Dr. K. Sugamura and Dr. S. Taki for providing TU27 MAb. We also thank Kerstin Bachtenkirch,

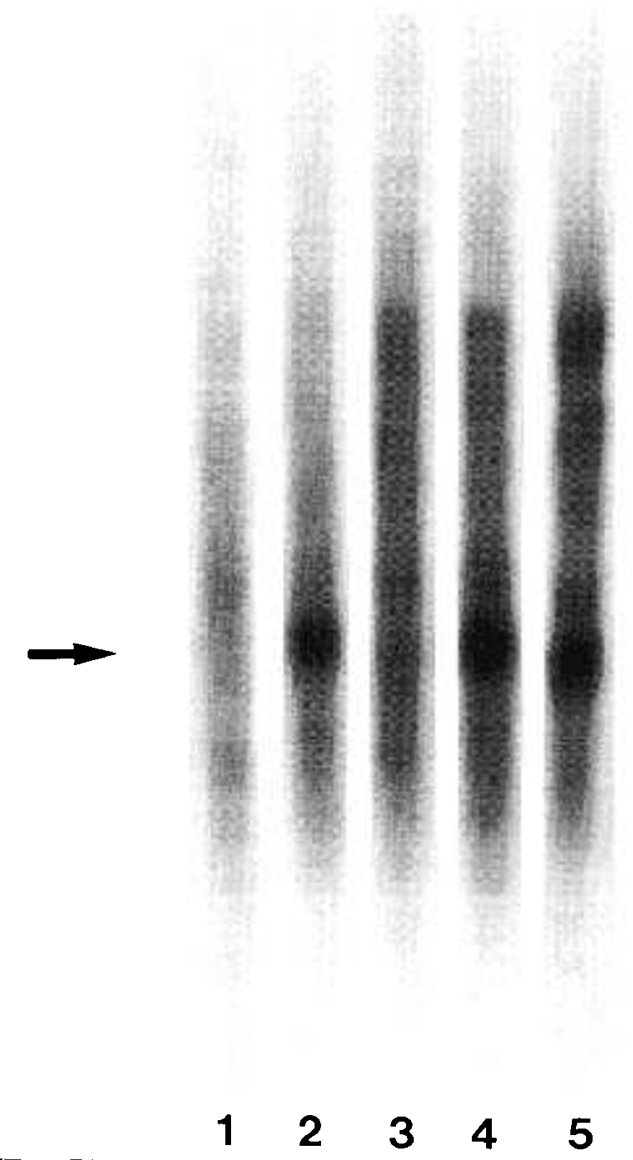

Fig. 7. IF $\gamma$ mRNA accumulation in neonatal $\mathrm{T}$ cells. Northern analysis of IF $\gamma$ mRNA of neonatal T cells stimulated under various conditions: lane 1 : unstimulated neonatal $\mathrm{T}$ cells; lane 2 : unstimulated neonatal $\mathrm{T}$ cells cultured with $100 \mathrm{U} / \mathrm{mL}$ IL-2; lane 3: CD3-stimulated neonatal T cells; lane 4: CD3-stimulated neonatal T cells cultured with $100 \mathrm{U} / \mathrm{mL}$ IL-2; lane 5: neonatal $\mathrm{T}$ cells preincubated with TAC MAb before stimulation with $\mathrm{CD} 3$ and cultured with $100 \mathrm{U} / \mathrm{mL}$ IL-2.

Cora Fried, and Dorothea Humbert for their expert technical assistance.

\section{REFERENCES}

1. Gotoff SP 1974 Neonatal immunity J Pediatr $85: 149-154$

2. Wilson CB, Haas JE 1984 Cellular defenses against toxoplasma gondii in newborns. J Clin Invest 73:1606-1616

3. Wilson CB 1986 Immunologic basis for increased susceptibility of the neonate to infection. J Pediatr 108:1-12

4. Wakasugi N, Virelizier JL, Arenzana-Seisdedos F, Rothhut B, Huerta JM, Russo-Marie F, Fiers W 1985 Defective IFN- $\gamma$ production in the human neonate. II. Role of increased sensitivity to the suppressive effects of prostaglandin E. J Immunol 134:172-176

5. Wilson CB, Westall J, Lewis DB, Dower SK, Alpert AR 1986 Decreased production of interferon-gamma by human neonatal cells. $J$ Clin Invest 77:860-867

6. Bryson YJ, Winter HS, Grad SE, Fischer TJ, Stiehm ER 1980 Deficiency of immune interferon production by leukocytes of normal newborns. Cell Immunol 55:191-200

7. Trinchieri G, Perussia B 1985 Immune interferon: a pleiotropic lymphokine with multiple effects. Immunol Today 6:131-136

8. Friedman RM, Vogel SN 1983 Interferons with special emphasis on the immune system. Adv Immunol 34:97-140

9. van Valen F, Piechot G, Burdach S, Jürgens H, Göbel U 1990 Synergistic cytotoxic effects of interferon- $\gamma$ and tumor necrosis factor- $\alpha$ on Ewing's bone tumor cell lines. Calcif Tissue Int 46(suppl, 2):A60(abstr 230)

10. Nathan CF, Murray HW, Wiebe ME, Rubin BY 1983 Identification of interferon- $\gamma$ as the lymphokine that activates human macrophage oxidative metabolism and antimicrobial activity. J Exp Med 158:670-689

11. Suzuki Y, Orellana MA, Schreiber RD, Remington JS 1988 Interferon- $\gamma$ : the major mediator of resistance against toxoplasma gondii. Science 240:516518

12. Kasahara T, Hooks JJ, Dougherty SF, Oppenheim JJ 1983 Interleukin 2- 
mediated immune interferon (IFN- $\gamma$ ) production by human $\mathrm{T}$ cells and $\mathrm{T}$ cell subsets. J Immunol 130:1784-1789

13. Reem GH, Yeh N 1984 Interleukin 2 regulates expression of its receptor and synthesis of gamma interferon by human T lymphocytes. Science 225:429430

14. Farrar WL, Johnson HM, Farrar JJ 1981 Regulation of the production of immune interferon and cytotoxic T lymphocytes by interleukin 2 . J Immunol 126:1120-1125

15. Smith KA 1988 Interleukin-2: inception, impact, and implications. Science 240:1169-1176

16. Fletcher M, Goldstein AL 1987 Recent advances in the understanding of the biochemistry and clinical pharmacology of interleukin-2. Lymphokine Res 6:45-57

17. Smith KA 1988 The interleukin 2 receptor. Adv Immunol 42:165-179

18. Wang H, Smith KA 1987 The interleukin 2 receptor. J Exp Med 16:10551069

19. Ohashi Y, Takeshita T, Nagata K, Mori S, Sugamura K 1989 Differential expression of the IL-2 receptor subunits, $\mathrm{p} 55$ and $\mathrm{p} 75$ on various populations of primary peripheral blood mononuclear cells. J Immunol 143:3548-3555

20. Robb RJ, Greene WC, Rusk CM 1984 Low and high affinity cellular receptors for interleukin 2. J Exp Med 160:1126-1146

21. Welte K, Andreeff M, Platzer E, Holloway K, Rubin BY, Moore MAS, Mertelsmann R 1984 Interleukin 2 regulates the expression of TAC antigen on peripheral blood T lymphocytes. J Exp Med 160:1390-1403

22. Smith KA, Cantrell DA 1985 Interleukin 2 regulates its own receptor. Proc Natl Acad Sci USA 82:864-868

23. Robb RJ, Greene WC 1987 Internalization of interleukin 2 is mediated by the $\beta$ chain of the high-affinity interleukin 2 receptor. J Exp Med 165:12011206

24. Fung MR, Ju G, Greene WC 1988 Co-internalization of the p55 and p70 subunits of the high-affinity human interleukin 2 receptor. J Exp Med 168:1923-1928

25. Valge VE, Wong JGP, Datlof BM, Sinskry AJ, Rao A 1988 Protein kinase C is required for responses to T cell receptor ligands but not to interleukin-2 in $\mathrm{T}$ cells. Cell $55: 101-112$

26. Tigges MA, Casey LS, Koshland ME 1989 Mechanism of interleukin-2 signaling: mediation of different outcomes by a single receptor and transduction pathway. Science 243:781-786

27. Hatakeyama M, Doi T, Kono T, Maruyama M, Minamoto S, Mori $H$ Kobayashi M, Yuchiyama T, Taniguchi T 1987 Transmembrane signaling of interleukin 2 receptor. J Exp Med 166:362-375

28. Mills GB, Girard P, Grinstein S, Gelfand EW 1988 Interleukin-2 induces proliferation of $\mathrm{T}$ lymphocyte mutants lacking protein kinase C. Cell 55:91100

29. Mills GB, May C, McGill M, Fung M, Baker M, Sutherland R, Greene WC 1990 Interleukin 2-induced tyrosine phosphorylation. J Biol Chem 265:3561-3567

30. Uchiyama T, Broder S, Waldmann TA 1981 A monoclonal antibody (anti$\mathrm{Tac})$ reactive with activated and functionally mature human cells. J Immunol 126:1393-1397

30a.Gray PW, Leung DW, Pennica D, Yelverton E, Najarian R, Simonsen CC Derynck R, Sherwood PJ, Wallace DM, Berger SL, Levinson AD, Goeddel DV 1982 Expression of human immune interferon cDNA in $E$. coli and monkey cells. Nature 295:503 508

31. Yagita H, Nakata M, Azuma A, Nitta T, Takeshita T, Sugamura K, Okumura K 1989 Activation of peripheral blood T cells via the p75 interleukin 2 receptor. J Exp Med 170:1445-1450

32. Burdach S, Zessack N, Dilloo D, Shatsky M, Thompson D, Levitt L 1991 Differential modulation of lymphokine production by distinct subunits of the T cell IL2 receptor. J Clin Invest 87:2114-2127

33. Winter HS, Gard SE, Fischer TJ, Bryson YJ, Stiehm ER 1983 Deficien lymphokine production of newborn lymphocytes. Pediatr Res 17:573-578

34. Kibler R, Hicks MJ, Wright AL, Taussig LM 1986 A comparative analysis of cord blood and adult lymphocytes: interleukin-2 and interferon production, natural killer cell activity, and lymphocyte populations. Diagn Clin Immuno 4:201-208

35. Rubin LA, Hoekzema GS, Nelson DL, Greene WC, Jay G 1987 Reconstitution of a functional interleukin 2 receptor in a nonlymphoid cell. $J$ Immunol 139:2355-2360

36. Takeshita T, Goto Y, Tada K, Nagata K, Asao H, Sugamura K 1989 Monoclonal antibody defining a molecule possibly identical to the p75 subunit of interleukin 2 receptor. J Exp Med 169:1323-1332

37. Gerli R, Bertotto A Crupi S, Arcangeli C Marinelli I Spinozzi F, Cernetti C, Angelella P, Rambotti P 1989 Activation of cord T lymphocytes. I. Evidence for a defective $T$ cell mitogenesis induced through the $\mathrm{CD} 2$ molecule. J Immunol 142:2583-2589

38. Burdach S, Shatsky M, Wagenhorst B, Levitt L 1988 The T-cell CD2 determinant mediates inhibition of erythropoiesis by the lymphokine cascade. Blood 72:770-775

39. Burdach SE, Levitt LJ $1988 \mathrm{~T}$ cell regulated hematopoiesis-molecular interactions in hematopoietic control by $\mathrm{CD} 2$ and interleukin 2. Behring Ins Mitt 83:56-67

40. Lewis DB, Larsen A, Wilson CB 1986 Reduced interferon-gamma mRNA levels in human neonates. J Exp Med 163:1018-1023 